\title{
Analysis and Research of Tianjin Development
}

\author{
Hong Liu \\ Beijing Wuzi University, Beijing, China \\ Email: liuhong_cc66@yahoo.com
}

Received 30 June 2016; accepted 31 July 2016; published 3 August 2016

Copyright (C) 2016 by author and Scientific Research Publishing Inc.

This work is licensed under the Creative Commons Attribution International License (CC BY). http://creativecommons.org/licenses/by/4.0/

(c) (i) Open Access

\begin{abstract}
Tianjin is an integral and important city in China. Tianjin's development influences China's development. In today's society, the coordinated development of Beijing and Tianjin has become a key consideration. It is also a goal we should strive; therefore, the development of Tianjin is one of the focuses of our study. This paper uses SPSS analysis. The data include agricultural output, the number of enterprises, logistics and transport. This paper studies the main factors in Tianjin, and we use the method of principal component analysis. Agriculture and heavy industry are quite developed in Tianjin. The paper also studies the common development of Tianjin. We concluded that we cannot ignore the simultaneous development of agriculture and heavy industry. In addition, we also study the Tianjin's logistics transportation equipment. We have come to the main road and rail transportation equipment. Finally, we do a short-term forecast on the amount of goods, which proves the feasibility of SPSS analysis.
\end{abstract}

\section{Keywords}

SPSS Analysis, Agricultural Output, Tianjin

\section{Introduction}

Beijing, Tianjin and China's developments are getting more and more attention by us. The development of Beijing, Tianjin and Shanghai cities will directly affect China's economic development. The main object of this study is Tianjin. Tianjin is a very prosperous region. The content of this paper is the Tianjin's economic factors, the development of agriculture, logistics and transportation. Tianjin's future trends provide a reliable basis. Many scholars have made a profound study on the development of Tianjin. Zheng Li, and Dai Ying (2015), two scholars summed up the basic goals and needs of Tianjin's economic development and economic construction from the point of view of national planning. Yang Wei, Xu Xuezeng, \& Hong Haiyu (2012) valued the em- 
ployment situation in Tianjin and the Tianjin economic. They thought that the economic development of Tianjin would lead Tianjin to promote employment. Wu Jingkun (2012) considered the development of Tianjin culture and the need to innovate to optimize the flow of commerce personnel work together to make recommendations promote the flow of commerce from the economic foundations. Jiang Xiaochuang (2014) thought that Tianjin has the advantage of the port; Tianjin should make use of port resources and the promotion of port throughput; Tianjin should promote common economic development. Liu Haiyuan and Wu Jinlong (2009) put forward that Tianjin needs the development of logistics; the limiting factor is the shortage of practical talents. Yang Guoliang (2006) proposed that the logistics development of Tianjin needs to adapt to the current national policies. Most scholars analyzed from the factors which affect the development of Tianjin, but they were lack of the data analysis and they did not do in-depth research on the specific situation in Tianjin. Based on the fact, we use a lot of data to analyze it and solve the problem.

\section{Tianjin Comprehensive Index Analysis}

Principal component analysis method is often used by researchers, principal component analysis can explore a region of the main factors, Therefore, this paper in order to obtain the main factors influence the development of Tianjin, a comprehensive analysis using SPSS software. Firstly, select the total agricultural output value of Tianjin, has a number of enterprises, the number of logistics and transport, light industry and heavy industry to judge and analyze comprehensive index Tianjin. In order to obtain satisfactory results, and data reliability, we took data from 2000 to 2013, the 2014 data also did not give specific numerical data are shown in Table 1.

After factor analysis, correlation coefficient matrix can be drawn, the results as shown in Table 2.

Table 1. Tianjin comprehensive index statistics.

\begin{tabular}{lccccc}
\hline Year & $\begin{array}{c}\text { Gross } \\
\text { output value }\end{array}$ & $\begin{array}{c}\text { Number of } \\
\text { enterprises (unit) }\end{array}$ & $\begin{array}{c}\text { Passenger } \\
\text { traffic (10,000 persons) }\end{array}$ & $\begin{array}{c}\text { Light } \\
\text { industry }\end{array}$ & $\begin{array}{c}\text { Heavy } \\
\text { industry }\end{array}$ \\
\hline 2000 & 156.30 & 456 & 3474 & 1263.10 & 1817.64 \\
2001 & 169.51 & 420 & 3302 & 1153.73 & 2212.80 \\
2002 & 181.07 & 925 & 3457 & 1207.88 & 2509.84 \\
2003 & 193.44 & 900 & 3507 & 1254.68 & 3116.08 \\
2004 & 221.35 & 1155 & 4103 & 1398.65 & 4787.39 \\
2005 & 238.34 & 1108 & 4679 & 1569.06 & 5600.56 \\
2006 & 225.04 & 1103 & 5670 & 1664.03 & 7243.42 \\
2007 & 240.74 & 1113 & 7104 & 1967.37 & 8535.54 \\
2008 & 268.11 & 1362 & 8753 & 2190.54 & $10,852.37$ \\
2009 & 281.65 & 1371 & 25,299 & 2290.38 & $11,093.87$ \\
2010 & 317.33 & 1448 & 24,873 & 2800.45 & $14,306.74$ \\
2011 & 349.48 & 1494 & 25,331 & 3746.71 & $17,781.63$ \\
2012 & 375.62 & 1648 & 28,462 & 4728.22 & $19,465.91$ \\
\hline
\end{tabular}

Table 2. Correlation matrix.

\begin{tabular}{|c|c|c|c|c|c|}
\hline Correlation & $\begin{array}{c}\text { Gross } \\
\text { output value }\end{array}$ & $\begin{array}{c}\text { Number of } \\
\text { enterprises (unit) }\end{array}$ & $\begin{array}{c}\text { Passenger } \\
\text { traffic }\end{array}$ & $\begin{array}{c}\text { Light } \\
\text { industry }\end{array}$ & $\begin{array}{l}\text { Heavy } \\
\text { industry }\end{array}$ \\
\hline Gross output value & 1.000 & 0.930 & 0.923 & 0.955 & 0.990 \\
\hline Number of enterprises (unit) & 0.930 & 1.000 & 0.818 & 0.816 & 0.905 \\
\hline Passenger traffic & 0.923 & 0.818 & 1.000 & 0.880 & 0.930 \\
\hline Light industry & 0.955 & 0.816 & 0.880 & 1.000 & 0.954 \\
\hline Heavy industry & 0.990 & 0.905 & 0.930 & 0.954 & 1.000 \\
\hline
\end{tabular}


From the data in Table 2, we can know the degree of correlation between the five variables are very high, for example, the correlation coefficient contribution of the agricultural economy and heavy industry output value is 0.990, reached a high degree of correlation, therefore, the data analyze the composition of the shots significant variables. Tianjin heavy industry should pay attention to the factors that strengthen the management of heavy industry, optimize the structure and organization of basic industry is the basis for the rational development of Tianjin.

From Table 3, we can know, after analysis software, it can mainly extract a principal component, software principle is selected eigenvalues greater than 1 is our target selected, the data in the first primary eigenvalues component is 4.643 , the remaining components of the eigenvalues are less than one, so we selected a main component is the first one. And the first principal component can explain 93\% of the original information of all the variables, it is a very reliable and value can be applied to real life.

The data in Table 4 tells us that the main component of the equation can be used to extract the following regression equation:

$$
F_{1}=0.996 * X_{1}+0.927 * X_{2}+0.945 * X_{3}+0.956 * X_{4}+0.993 * X_{5}
$$

among them:

$X_{1}$ : Gross Output Value.

$X_{2}$ : Number of Enterprise.

$X_{3}$ : Passenger Traffic.

$X_{4}$ : Light Industry.

$X_{5}$ : Heavy Industry.

These data tell us that after data processing and standardized regression coefficients of significant indicators, we can know that how much can be seen that the main component of agriculture can be replaced, because agriculture is the coefficient 0.996, the entire data is a maximum. These results suggest that the development of Tianjin's economy depends mainly on agriculture, therefore, it is to strengthen the focus of Beijing, Tianjin and the Tianjin development of agriculture and protection.

Table 3. Total variance explained.

\begin{tabular}{ccccccc}
\hline \multirow{2}{*}{ Ingredient } & \multicolumn{3}{c}{ Initial eigenvalues } & \multicolumn{2}{c}{ Extracting square and load } \\
\cline { 2 - 6 } & Total & Variance \% & Accumulation \% & Total & Variance \% & Accumulation \% \\
\hline 1 & 4.643 & 92.866 & 92.866 & 4.643 & 92.866 & 92.866 \\
3 & 0.205 & 4.110 & 96.975 & & \\
4 & 0.125 & 2.495 & 99.470 & & \\
5 & 0.021 & 0.417 & 99.887 & & \\
& 0.006 & 0.113 & 100.000 & & \\
\end{tabular}

Table 4. Composition matrix.

\begin{tabular}{lll}
\hline & Ingredient \\
& & 1 \\
\hline$X_{1}$ & 0.996 \\
$X_{3}$ & 0.927 \\
$X_{4}$ & 0.945 \\
$X_{5}$ & 0.956 \\
\hline
\end{tabular}




\section{Logistics Transportation Equipment}

Tianjin logistics transportation equipment is an important factor affecting economic development in Tianjin, logistics equipment determines the transport speed of logistics and products, mainly logistics and transport equipment Tianjin rail, road and water transport, under the leadership of logistics equipment, each year in Tianjin will have a lot cargo, but depending on which freight transport logistics and equipment, it is worth our study. This article taken correlation coefficient and regression methods to examine the data, the data shown in Table 5, the results of the test are shown in Table 6 and Table 7.

From the correlation coefficient, we can see that the correlation coefficient and cargo railway is 0.9 , which is rendered highly correlated and road freight is 0.765 , which is showing a moderate correlation, cargo and water transport the correlation coefficient is 0.838 , which showed a high correlation, indicating that the main use of the logistics of Tianjin railway and water transport, railway transport capacity mainly for cargo, quantity, unit area of small goods, water generally relates to a very wide range, it including between countries, between the coastal cities of transport logistics.

After analysis of regression equations, linear equations we can draw is:

$$
W=0.958 * U_{1}+1.051 * U_{2}+1.059 * U_{3}-605.635
$$

The meaning of the equation is the three streams of cargo and transport equipment exhibits a linear relationship with the increase in rail, road and waterway transport, cargo is showing a rise in the value of times, they exhibit proportional relationship.

Finally, we made the prediction model, predicted results are in line with freight data ARIMA $(0,1,0)$ model prediction, graphic prediction model as shown in Figure 1 is a graphical representation of the gradual increase

Table 5. Tianjin logistics transportation equipment.

\begin{tabular}{ccccc}
\hline Year & Freight traffic & Railways & Highways & Waterways \\
\hline 2000 & 26,400 & 3079 & 18,764 & 4165 \\
2001 & 28,608 & 3727 & 19,382 & 5037 \\
2002 & 31,016 & 4519 & 19,554 & 6452 \\
2003 & 35,252 & 5662 & 20,072 & 8944 \\
2004 & 37,934 & 6108 & 19,560 & 11,613 \\
2005 & 40,263 & 7241 & 19,850 & 12,375 \\
2006 & 42,863 & 8409 & 20,290 & 13,313 \\
2007 & 51,338 & 11,288 & 23,500 & 15,671 \\
2008 & 55,065 & 12,161 & 27,000 & 15,096 \\
2009 & 43,554 & 11,284 & 19,800 & 11,656 \\
2010 & 41,611 & 7597 & 20,855 & 11,911 \\
2011 & 44,651 & 7286 & 23,426 & 12,711 \\
2012 & 47,698 & 7909 & 28,228 & 10,332 \\
2013 & 51,603 & 8446 & 31,985 & 9884 \\
\hline
\end{tabular}

Table 6. Correlation analysis.

\begin{tabular}{cccccc}
\hline & & Freight traffic & Railways & Highways & Waterways \\
\multirow{2}{*}{ Freight traffic } & Pearson & 1 & $0.900^{* *}$ & $0.765^{* *}$ & $0.838^{* *}$ \\
& Sig & & 0.000 & 0.001 & 0.000 \\
\hline
\end{tabular}

Table 7. Regression equations.

\begin{tabular}{cccccc}
\hline Model & & B Deviation trial version & Sig. & 0.130 \\
\hline Constant & -605.635 & 367.528 & 0.304 & -1.648 \\
Railways & 0.958 & 0.047 & 0.487 & 20.365 \\
Highways & 1.051 & 0.017 & 0.422 & 61.082 \\
Waterways & 1.059 & 0.035 & 30.444 & 0.000 \\
\hline
\end{tabular}




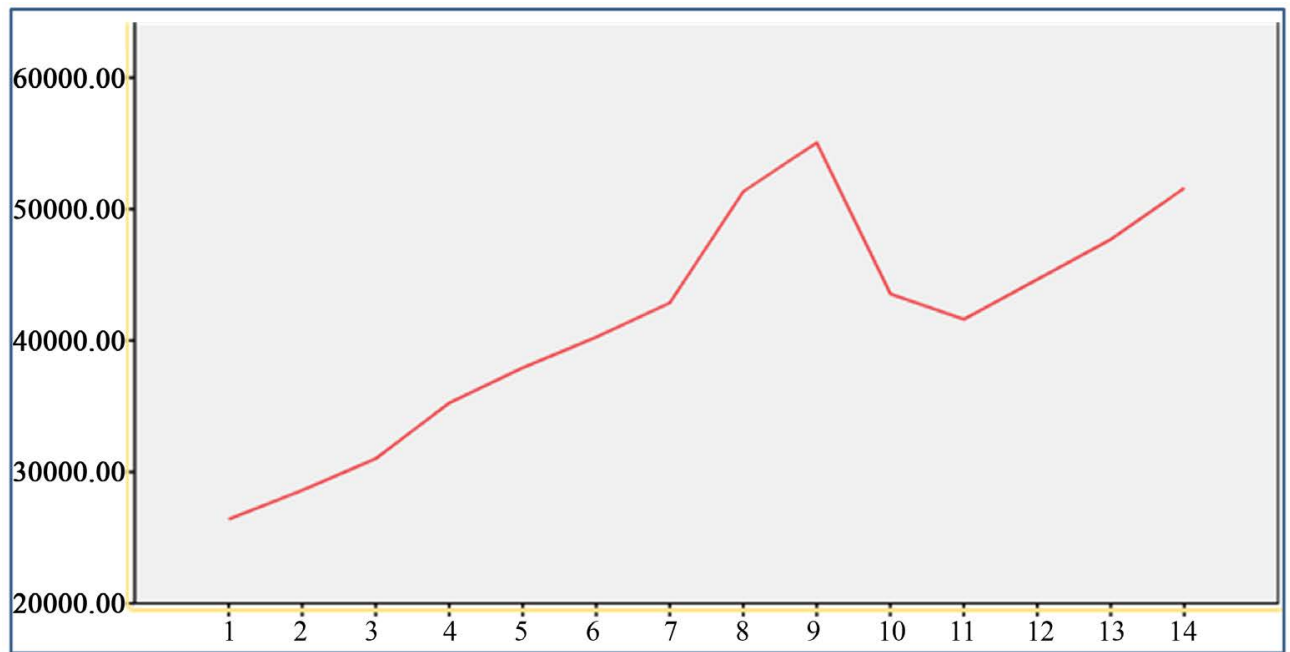

Figure 1. Predictive model. Note: X-axis represents the predicted time point; Y-axis represents the model coefficients.

in the year, cargo showed an increasing trend and it is expected in 2014 to 2016, 2011 to 2014 data show an upward trend, so we expect the 2015 and 2016 data will continue to rise. Tianjin cargo volume will continue to rise, it is a strong basis for economic development in Tianjin.

\section{Summary}

Tianjin's development is inseparable from the efforts of each other. We should seize the development of Tianjin's agriculture and vigorously develop the agricultural economy. Agricultural development needs the starting from the farmer skills. The local government should make use of Internet technology. The government can spread advanced network platform and guide farmers to learn advanced techniques and theoretical knowledge. For example, the planting outstanding cases are made into a video. It will be spread to the network platform and it will be learned by farmers. In addition, Tianjin should make use of local developed logistics and transport equipment, and make effective combination of rail and road. Tianjin should protect the product quality and safety in the aspect of logistics. When it is necessary, the government should vigorously promote enterprises to establish reasonable safety stock, and reduce transport of goods. It will reduce transport costs and improve service quality. Finally, Tianjin should strengthen the training of staffs. On one hand, it is important to strengthen the capacity of staff hands-on. On the other hand, Tianjin city trains more excellent talents which is also a good way to accelerate the development of Tianjin. It will strengthen the cooperation with Beijing.

\section{References}

Jiang Xiaochuang 蒋晓闯 (2014). Port as Tianjin Economic Development Breakthrough Resource Advantages Path Analysis 以港口为天津经济发展新突破的资源优势路径分析. Tianjin Economic, 2, 22-25.

Liu Haiyuan, \& Wu Jinlong. 刘海远, 吴金龙 (2009). Analysis of Tianjin Logistics Management Career Prospects 浅析天 津物流管理职业前景. Productivity Research, 18, 106-107.

Wu Jingkun 吴静坤 (2012). Innovation and Trade Flows-Tianjin Economic Development of Power and Path 自主创新 和商贸流通一一天津经济发展的动力和路径. Financial Times, 9, 190-193.

Yang Guoliang 杨国良 (2006). Infrastructure and Level of Development of the Logistics Industry in Tianjin Statistical Analysis 天津物流业基础设施及发展水平统计分析. Modern Finance and Economics (Journal of Tianjin University of Finance and Economics), 6, 72-75.

Yang Wei, Xu Xuezeng, \& Hong Haiyu 杨维, 徐学增, 洪海钰 (2012). Tianjin’s Economic Development and Employment Growth 天津经济发展与就业增长的关系研究. Research World, 2, 8-12.

Zheng Li, \& Dai Ying 郑礼，戴颖 (2015). “1025” Period Reviewed Tianjin Economic Development “十二五”时期天津经 济发展综述. Tianjin Economic, 8, 5-8. 


\section{Submit or recommend next manuscript to SCIRP and we will provide best service for you:}

Accepting pre-submission inquiries through Email, Facebook, LinkedIn, Twitter, etc.

A wide selection of journals (inclusive of 9 subjects, more than 200 journals)

Providing 24-hour high-quality service

User-friendly online submission system

Fair and swift peer-review system

Efficient typesetting and proofreading procedure

Display of the result of downloads and visits, as well as the number of cited articles

Maximum dissemination of your research work

Submit your manuscript at: http://papersubmission.scirp.org/ 